\title{
Triiodothyronine, Thyroxine, and Iodine in Purified Thyroglobulin from Patients with Graves' Disease
}

\author{
M. IZUMI and P. REED LARSEN \\ From the Thyroid Unit, Department of Medicine, Peter Bent Brigham Hospital, and Harvard \\ Medical School, Boston, Massachusetts 02115
}

A B S T RACT Previous studies have suggested that there is an overproduction of triiodothyronine $\left(\mathrm{T}_{3}\right)$ relative to thyroxine $\left(\mathrm{T}_{4}\right)$ in patients with thyrotoxicosis associated with Graves' disease. To evaluate whether or not an increased ratio of $T_{3}$ to $T_{4}$ in thyroidal secretion could be contributing to this relative $T_{3}$ hyperproduction, $T_{3}, T_{4}$, and iodine were measured in thyroglobulin ( $\mathrm{Tg}$ ) from controls and patients with Graves' disease who had been treated either with propranolol only or with antithyroid drugs plus iodide before surgery. To avoid possible artifacts associated with pulse labeling and chromatography, $T_{3}$ and $T_{4}$ were determined by radioimmunoassay of Pronase hydrolysates of purified Tg. Results of analyses of $\mathrm{Tg}$ from six control patients and seven with Graves' disease, not receiving thiourea drugs or iodide, showed that the iodine content of Graves' disease $\mathrm{Tg}$ was not different from normal. Both contained 3.4 residues of $\mathrm{T}_{4} /$ molecule $\mathrm{Tg}$, but there was $0.39 \pm 0.08$ (mean $\pm \mathrm{SD}$ ) residue of $\mathrm{T}_{3} /$ molecule $\mathrm{Tg}$ in Graves' $\mathrm{Tg}$ as opposed to $0.23 \pm 0.07$ residue $\mathrm{T}_{3}$ molecule $\mathrm{Tg}$ in controls matched for iodine content $(P<0.01)$. This difference resulted in a significantly lower $\mathrm{T}_{4} / \mathrm{T}_{3}$ molar ratio $(9 \pm 2)$ in Graves' $\mathrm{Tg}$ as opposed to control $(15 \pm 2, P<0.001)$. In $\mathrm{Tg}$ from patients with treated Graves' disease, iodine, $\mathrm{T}_{3}$, and $\mathrm{T}_{4}$ were reduced, but the reduction in the latter was more substantial, resulting in a $\mathrm{T}_{4} / \mathrm{T}_{3}$ molar ratio of 3.4 \pm 1 . Fractionation of $\mathrm{Tg}$ from all groups by $\mathrm{RbCl}$ density gradient ultracentrifugation indicated that at physiological levels of $\mathrm{Tg}$ iodination, the molar ratio of $\mathrm{T}_{3} / \mathrm{Tg}$ was consistently higher in Graves' disease. The specific mechanism for this difference is not

This work was presented in part at the 52nd Annual Meeting of the American Thyroid Association, Toronto, Ontario, Canada, 15-18 September 1976.

Dr. Larsen is an Investigator of the Howard Hughes Medical Institute.

Received for publication 7 October 1976 and in revised form 7 February 1977.

The Journal of Clinical Investigation known, but it is not due to iodine deficiency. If $T_{3}$ and $T_{4}$ are secreted in this altered ratio in patients with Graves' disease, the magnitude of the difference could explain the relative $T_{3}$ hyperproduction which is characteristic of this state.

\section{INTRODUCTION}

There is considerable evidence that the hyperthyroidism associated with Graves' disease is accompanied by hyperproduction of triiodothyronine $\left(\mathrm{T}_{3}\right)^{1}$ relative to thyroxine $\left(\mathrm{T}_{4}\right)(1)$. The most extreme example of this phenomenon is found in the patient with the clinical stigmata of hyperthyroidism, a normal serum $T_{4}$ and elevated serum $T_{3}$, a condition which has been called " $T_{3}$ thyrotoxicosis" (2). Previous studies from our laboratory have suggested that the contribution of direct thyroidal secretion to the peripheral $T_{3}$ pool in thyrotoxicosis is greater than in the euthyroid subject $(3,4)$. Studies of digests of thyroid homogenates from normal subjects and patients with treated Graves' disease showed that the molar ratio of $T_{3}$ to $T_{4}$ in the thyroid glands of patients with treated Graves' disease was higher than in normal subjects (4). However, because of the pretreatment of these subjects with antithyroid agents, iodine content was reduced. Since reduction in iodine content per se gives rise to thyroglobulin $(\mathrm{Tg})$ with an increased $\mathrm{T}_{3} / \mathrm{T}_{4}$ molar ratio (5), it was not possible to determine if the high $\mathrm{T}_{3} / \mathrm{T}_{4}$ ratio was due to Graves' disease or iodine deficiency itself. Preliminary data obtained in homogenates of thyroid tissue from two patients who were treated only with propranolol before therapy showed only a modest reduction in iodine content, but a marked increase in the $T_{3} / T_{4}$ ratio (4). Because this suggested that there might be an additional factor(s) besides iodine regulating the ratio of

${ }^{1}$ Abbreviations used in this paper: $\mathrm{T}_{3}, 3,5,3^{\prime}$-triiodo- $\mathrm{L}-$ thyronine; $\mathrm{T}_{4}, 3,5,3^{\prime}, 5^{\prime}$-tetraiodo-L-thyronine; $\mathrm{Tg}$, thyroglobulin. 
TABLE I

Results of Analyses of Serum $T_{4}$ and $T_{3}$ at the Time of Surgery in Patients with Graves' Disease

\begin{tabular}{|c|c|c|c|c|}
\hline Subject & Presurgical therapy & $\mathrm{T}_{4}$ & $\begin{array}{l}\mathrm{T}_{3} \text { Resin } \\
\text { uptake }\end{array}$ & $\begin{array}{c}\mathrm{T}_{3} \text { Radio- } \\
\text { immunoassay }\end{array}$ \\
\hline & & $\mu g / 10() \mathrm{ml}$ & $\%$ & $n g / 100 \mathrm{ml}$ \\
\hline \multicolumn{5}{|l|}{ Normal } \\
\hline range & & $5.4-1: 3.4$ & $22-34$ & $80-210$ \\
\hline 1 & Propranolol & $>25$ & 52 & $>5(1)$ \\
\hline 2 & Propranolol & $>25$ & 54 & - \\
\hline 3 & Propranolol & 18 & 45 & - \\
\hline 4 & Propranolol & 20 & 44 & - \\
\hline 5 & Propranolol & 22 & 51 & - \\
\hline 6 & Propranolol & 20) & 50 & $>300$ \\
\hline \multirow[t]{3}{*}{7} & Propranolol & 23 & 51 & - \\
\hline & & $\begin{array}{c}\mathrm{T}_{4} \text { Radio- } \\
\text { immuno- } \\
\text { assay }\end{array}$ & $\begin{array}{c}\mathrm{T}_{4} \text {-Binding } \\
\text { globulin } \\
\text { index* }\end{array}$ & $\begin{array}{c}\mathrm{T}_{3} \text { Radio- } \\
\text { immunoassay }\end{array}$ \\
\hline & & $\mu \mathrm{g} / 10() \mathrm{ml}$ & & $\mathrm{ng} / \mathrm{l}(0) \mathrm{ml}$ \\
\hline $\begin{array}{r}\text { Normal } \\
\text { range }\end{array}$ & & $5-10.2$ & $0.85-1.10$ & $65-160$ \\
\hline 8 & $\begin{array}{l}\text { 6-n-Propylthiouracil, } \\
\text { SSKI, propranolol }\end{array}$ & 5.8 & 0.66 & 100 \\
\hline 9 & $\begin{array}{l}\text { 6-n-Propylthiouracil, } \\
\text { SSKI, propranolol }\end{array}$ & 7.9 & - & - \\
\hline 10 & $\begin{array}{l}\text { 1-methyl,2-mer- } \\
\text { captoimdazole }\end{array}$ & 3.3 & 0.96 & 48 \\
\hline
\end{tabular}

* $\mathrm{T}_{4}$-binding globulin index-normalized $\mathrm{T}_{3}$ charcoal uptake.

$\mathrm{T}_{3} / \mathrm{T}_{4}$ synthesized in the stimulated thyroid of Graves' disease, the following investigation was performed.

\section{METHODS}

Sources of thyroid tissue. Specimens of human thyroid tissue were obtained from two sources. Patients whose only preoperative treatment was propranolol (referred to as "untreated" since they did not receive thiourea drugs or iodide) underwent subtotal thyroidectomy at Georgetown University in Washington, D. C. Specimens of thyroid tissue from these patients were kindly provided by Dr. J. J. Canary of that institution and were shipped frozen in dry ice, having been stored at $-20^{\circ} \mathrm{C}$ for various periods of up to several months. Specimens of thyroid tissue from patients with treated Graves' disease (thiourea drugs plus iodide) were obtained with the cooperation of members of the Departments of Surgery and Pathology at the Peter Bent Brigham Hospital. Control samples of tissue were obtained from portions of microscopically normal th yroid tissue in surgical specimens which were resected for thyroid nodules. All patients were clinically euthyroid at the time of surgery. Specimens were frozen immediately after their removal from the operating room and kept at $-20^{\circ} \mathrm{C}$. Control studies indicated that the results obtained using frozen and unfrozen tissue from the same patient with treated Graves' disease were identical.

Thyroglobulin preparation. Approximately $2-3 \mathrm{~g}$ of thyroid was cut into small pieces and put into an equal volume of $0.1 \mathrm{M}$ phosphate buffer $(\mathrm{pH}$ 7.19). This was homogenized with a Teflon pestle and centrifuged at $40,000 \mathrm{~g}$ for $20 \mathrm{~min}$ at $4^{\circ} \mathrm{C}$ in a Sorvall $\mathrm{RC} 2 \mathrm{~B}$ centrifuge (Ivan Sorvall, Inc., Norwalk, Conn.). The supernate was saved and pooled with the supernatant fraction of a single wash with the same buffer. Ammnoium sulfate precipitation was performed with a collection of insoluble material between the concentrations of 1.4 and $1.8 \mathrm{M}$ (6). Gel filtration on Bio-Gel A5M, 200-400 mesh, (Bio-Rad Laboratories, Richmond, Calif.) was performed using a $90 \times 2.6$-cm column in phosphate buffer at $4^{\circ} \mathrm{C}$ according to the method of Bilstad et al. (7). The concentration of $\mathrm{Tg}$ in the eluate of the $5-\mathrm{ml}$ fractions was determined spectrophotometrically (extinction coefficient, $280 \mathrm{~nm}, 1 \%$ solution $=10$ ). The $19 \mathrm{~S} \mathrm{Tg}$ was identified by its position in the elution pattern and the single peak fraction used for further studies. This protein gave a single band on disc gel electrophoresis.

Equilibrium density gradient centrifugation on $\mathrm{RbCl}$. Isopycnic centrifugation in $34.5 \% \mathrm{RbCl}$ was performed according to the method of Schneider and Edelhoch (8). A model L Beckman preparative centrifuge with SW 50.1 rotor was used (Beckman Instruments, Inc., Spinco Div., Palo Alto, Calif.) and centrifugation was performed for 5-7 days at $20^{\circ} \mathrm{C}$ at $33,000 \mathrm{rpm}$. Fractionation was obtained using the Buchler Auto Densi-Flow II C apparatus (Buchler Instruments Div., Searle Analytic Inc., Fort Lee, N. J.). 35 0.15-0.2-ml fractions were obtained from each tube. After protein quantitation, appropriate fractions were pooled and dialyzed against $500 \mathrm{ml}$ of $0.04 \mathrm{M}$ Tris- $0.11 \mathrm{M} \mathrm{NaCl}, \mathrm{pH}$ 8.5 for three 2-h periods to remove $\mathrm{RbCl}$. Measurements of iodine content and Pronase digestion were then performed.

Digestion of Tg. 20-40 $\mu \mathrm{g}$ of purified $\mathrm{Tg}$ (either after gel filtration or $\mathrm{RbCl}$ equilibrium centrifugation) in Tris$\mathrm{NaCl}$ was placed in a small plastic tube and digested according to the method of Inoue and Taurog (9). In addition to $100 \mu \mathrm{l}$ of the $\mathrm{Tg}$ solution, each tube contained $30 \mu \mathrm{l}$ of $0.15 \mathrm{M}$ l-methyl-2-mercaptoimidazole, (Aldrich Chemical Co. Milwaukee, Wis.) and $20 \mu \mathrm{l}$ of Pronase (B grade Calbiochem San Diego, Calif.) $3 \mathrm{mg} / \mathrm{ml}$ in Tris $\mathrm{NaCl}$ with $10 \mu \mathrm{l}$ toluene. Incubation was carried out for $24 \mathrm{~h}$ at $37^{\circ} \mathrm{C}$ under $\mathrm{N}_{2}$. Completeness of digestion was determined by quantitation of iodine remaining at the origin of a butanol-acetic acid chromatogram of unextracted digests of $\mathrm{Tg}$ from three control and three propranolol-treated patients. The appearance of $\mathrm{I}^{-}$during digestion (also in six samples) was determined by quantitation of iodine in the appropriate area of the chromatographic strip (butanol-acetic acid) as indicated by the location of ${ }^{125} I^{-}$which had been added in tracer amounts. The digests were extracted with $0.8 \mathrm{ml}$ methanol/concentrated ammonium hydroxide (99/l, vol/vol). Appropriate dilutions of this extract were made and radioimmunoassay of $T_{3}$ and $T_{4}$ performed in duplicate at two dilutions using minor modifications of methods previously described (10). Specimens from all controls and all Graves' thyroids were assayed simultaneously to avoid interassay variation. Iodine determinations were performed by Boston Medical Laboratory. Statistical comparisons were carried out using methods described by Snedecor and Cochran or, where indicated, by Fisher's Exact Treatment (11, 12).

\section{RESULTS}

Clinical data for subjects with Graves' disease. In Table I are presented the presurgical therapy and biochemical results relative to thyroid status of the patients with Graves' disease. The results of the first seven patients who received propranolol alone are typical of patients with untreated hyperthyroidism due to Graves' disease. $T_{3}$ determinations were available in only two patients and both were elevated. 


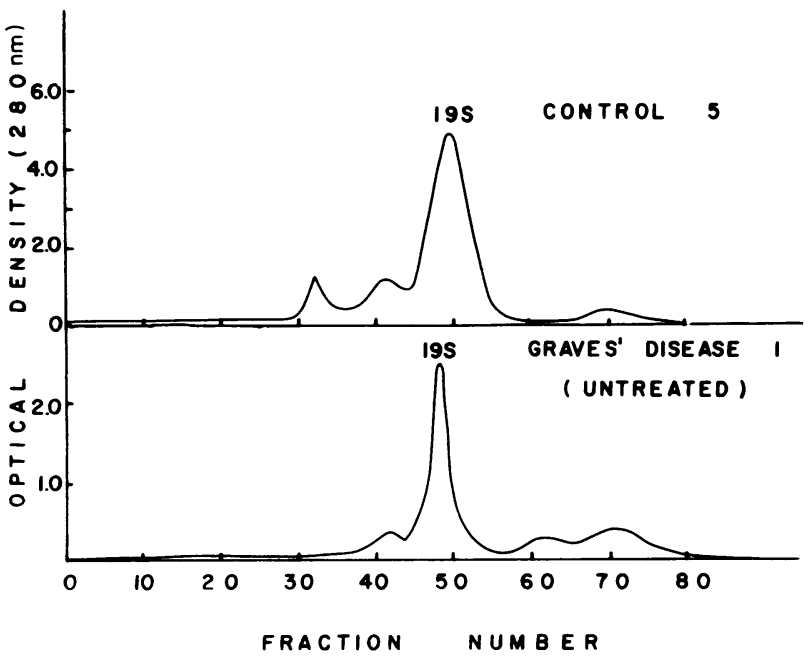

FIGURE 1 Typical elution patterns obtained by column chromatography of ammonium sulfate fractions of extracts from human thyroid tissue. Chromatography was performed with Bio-Gel A5M (Bio-Rad Laboratories), at $4^{\circ} \mathrm{C}$. Each fraction contains $5 \mathrm{ml}$. Representative patterns from a control thyroid (upper portion) and from thyroid tissue from a patient with Graves' disease are depicted. The term "untreated" indicates that the patient received propranolol but not thiourea drugs or iodide.

Patients 8-10 received various antithyroid drugs, and $\mathrm{T}_{4}$ results were in the normal range for two subjects and subnormal in subject 10 . None of these patients was clinically hypothyroid.

Results of iodine, $T_{3}$, and $T_{4}$ analyses. Fig. 1 depicts typical elution patterns of $\mathrm{Tg}$ from euthyroid patients and those with propranolol-treated Graves' disease. Aside from differences in the width of the peak associated with the degree of column loading, there was no apparent difference in elution patterns between these two groups of samples. In all subjects the $19 \mathrm{~S}$ peak was clearly delineated and constituted the greatest percentage of the protein present.

Measurements of $T_{3}, T_{4}$, and iodine, in $\mathrm{Tg}$ from control subjects are presented in Table II. The mean iodine content of the group was $0.42 \%$ corresponding to 22 atoms of iodine/molecule $\mathrm{Tg}$. The content of $\mathrm{T}_{3}$ and $\mathrm{T}_{4}$ per molecule $\mathrm{Tg}$ was 0.18 and 2.5 with a calculated molar ratio of 13 . When expressed as a percentage of the total $\mathrm{Tg}$ iodine, this corresponds to 2.4 and $41 \%$ for $\mathrm{T}_{3}$ and $\mathrm{T}_{4}$, respectively. The iodine content of two of the control $\mathrm{Tg}$ preparations was modestly reduced for reasons which were not apparent from the clinical history. In subject 1 this was associated with a $\mathrm{T}_{4}$ content which appeared to be considerably below that of the remainder of the group. Because of the reduced iodine content, and because of the fact that, as will be seen in Table III, the Graves' disease $\mathrm{Tg}$ was relatively rich in iodine, mean values were also calculated excluding subjects 1 and 2 to allow valid comparisons.

The results of analyses of $T_{3}, T_{4}$, and iodine content in the Tg from patients with Graves' disease is presented in Table III. $P$ values are calculated for comparison of results in the propranolol-treated subjects with the four control subjects with the higher iodine content using Students $t$ test (11). The mean iodine content of the $\mathrm{Tg}$ of the untreated Graves' disease patients was $0.56 \%$ corresponding to 29 atoms/molecule. This was identical to the group of four patients used as controls. Despite this, the $\mathrm{T}_{4} / \mathrm{Tg}$ ratio was 3.4 which was not different from the control group. This resulted in a significantly lower $T_{4} / T_{3}$ molar ratio of 9.0 for the $\mathrm{Tg}$ from patients with Graves' disease.

The lower portion of Table III presents the results of Tg analyses from patients with treated Graves' disease. Because of antithyroid drug treatment, the iodine content was markedly reduced in these subjects, being $0.16 \%$ or 6.5 atoms $/$ molecule. While the ratio of $\mathrm{T}_{3} / \mathrm{Tg}$ was reduced in these subjects, it was not reduced to as great a degree as was the $\mathrm{T}_{4} / \mathrm{Tg}$ ratio. Therefore, the $T_{4} / T_{3}$ ratio of 3.4 is lower than in $\mathrm{Tg}$ from propranolol-treated Graves' disease patients. The percent $T_{3}$ iodine was increased in these subjects and the percent $T_{4}$ iodine was reduced when compared with normals.

During Pronase digestion, $8.2 \pm 1.0 \%($ mean $\pm \mathrm{SE})$ of the $\mathrm{Tg}$ iodine was found as $\mathrm{I}^{-}$in incubations involving either control or Graves' disease Tg. If this iodine were derived, at least partly, from $T_{4}$ with $T_{3}$ as a by-product, then it is theoretically possible that greater deiodination of $T_{4}$ to $T_{3}$ could occur with

TABLE II

$T_{3}, T_{4}$, and I Content of Purified Human Tg from Euthyroid Subjects

\begin{tabular}{|c|c|c|c|c|c|c|c|}
\hline Subjects & $\begin{array}{c}\text { I } \\
\text { Content }\end{array}$ & $1 / \mathrm{Tg}$ & $\mathrm{T}_{3} / \mathrm{Tg}$ & $\mathrm{T} / \mathrm{Tg}$ & $T_{4} \sqrt{T_{3}}$ & $T_{3} \mathbf{I} / \mathbf{I}$ & $T_{4} \mathbf{I} / \mathbf{I}$ \\
\hline & $\%$ & $\begin{array}{c}\text { atoms/ } \\
\text { molecule }\end{array}$ & & olar ratio & & $\%$ & $\%$ \\
\hline \multicolumn{8}{|l|}{ Control } \\
\hline 1 & 0.13 & 6.6 & 0.046 & 0.33 & 7.2 & 2.1 & 20 \\
\hline 2 & 0.20 & 10 & 0.087 & 1.0 & 12 & 2.6 & 40 \\
\hline 3 & 0.44 & 23 & 0.13 & 2.2 & 18 & 1.6 & 39 \\
\hline 4 & 0.56 & 29 & 0.28 & 3.9 & 14 & 2.9 & 54 \\
\hline 5 & 0.54 & 28 & 0.24 & 3.6 & 15 & 2.6 & 52 \\
\hline 6 & 0.65 & 34 & 0.28 & 3.7 & 13 & 2.5 & 43 \\
\hline Mean & 0.42 & 22 & 0.18 & 2.5 & 13 & 2.4 & 41 \\
\hline SD & 0.21 & 11 & 0.10 & 1.5 & 4 & 0.5 & 12 \\
\hline Mean* & 0.55 & 29 & 0.23 & 3.4 & 15 & 2.4 & 47 \\
\hline SD & 0.09 & 5 & 0.07 & 0.8 & 2 & 0.6 & 7 \\
\hline
\end{tabular}

* Excluding subjects 1 and 2.

$T_{3}, T_{4}$ and Iodine in Human Thyroglobulin 
TABLE III

$T_{3}, T_{4}$, and I Content of Purified Tg from Patients with Graves' Disease

\begin{tabular}{cccccccc}
\hline Subjects & $\begin{array}{c}\mathrm{I} \\
\text { Content }\end{array}$ & $\mathrm{I} / \mathrm{Tg}$ & $\mathrm{T}_{3} / \mathrm{Tg}$ & $\mathrm{T}_{4} / \mathrm{Tg}$ & $\mathrm{T}_{4} / \mathrm{T}_{3}$ & $\mathrm{~T}_{3} \mathrm{I} / \mathrm{I}$ & $\mathrm{T}_{4} \mathrm{I} / \mathrm{I}$ \\
\hline & $\begin{array}{c}\text { atoms } / \\
\%\end{array} \quad$ molecule
\end{tabular}

Presurgical treatment with propranolol alone

$\begin{array}{cccccccc}1 & 0.33 & 17 & 0.32 & 2.9 & 9.0 & 5.6 & 67 \\ 2 & 0.48 & 25 & 0.26 & 3.1 & 12 & 3.2 & 50 \\ 3 & 0.55 & 28 & 0.45 & 2.6 & 5.7 & 4.8 & 36 \\ 4 & 0.56 & 29 & 0.37 & 3.4 & 9.3 & 3.8 & 47 \\ 5 & 0.63 & 33 & 0.45 & 4.4 & 9.8 & 4.1 & 54 \\ 6 & 0.65 & 34 & 0.41 & 3.5 & 8.4 & 3.6 & 41 \\ 7 & 0.69 & 36 & 0.47 & 3.9 & 8.9 & 3.9 & 44 \\ \text { Mean } & 0.56 & 29 & 0.39 & 3.4 & 9.0 & 4.1 & 48 \\ \text { SD } & 0.12 & 6 & 0.08 & 0.6 & 2.0 & 0.8 & 10 \\ P^{*} & \text { NS } & \text { NS } & <0.01 & \text { NS } & <0.001 & <0.005 & \text { NS }\end{array}$

Presurgical treatment with thiourea drugs and iodide

\begin{tabular}{rrrrrrrr}
8 & 0.13 & 6.6 & 0.18 & 0.46 & 2.6 & 8.1 & 28 \\
9 & 0.17 & 8.7 & 0.15 & 0.43 & 3.0 & 6.9 & 20 \\
10 & 0.19 & 4.2 & 0.13 & 0.58 & 4.5 & 4.2 & 24 \\
Mean & 0.16 & 6.5 & 0.15 & 0.49 & 3.4 & 6.4 & 24 \\
SD & 0.03 & 2.3 & 0.02 & 0.08 & 1.0 & 2.0 & 4 \\
\hline
\end{tabular}

* For difference from mean of control subjects three to six.

Graves' disease Tg as opposed to control Tg. This could result in an artifactual reduction of the $\mathrm{T}_{4} / \mathrm{T}_{3}$ ratio in Graves' Tg. To eliminate this possibility, labeled $\mathrm{T}_{4}$ was incubated with unlabeled control or Graves' disease Tg during Pronase digestion. Labeled $\mathrm{T}_{3}$ was then isolated by specific immunoadsorption to Sepharose-anti- $\mathrm{T}_{3}$ antibody conjugates prepared by methods to be published subsequently. ${ }^{2} \mathrm{~A}$ maximum of $0.74 \pm 0.15 \%$ (mean $\pm \mathrm{SD}$ ) of labeled $\mathrm{T}_{4}$ appeared as labeled $\mathrm{T}_{3}$ in incubations using Graves' disease $\mathrm{Tg}$ and $0.60 \pm 0.07 \%$ in the presence of control $\mathrm{Tg}$. These results were not different and even the maximum percent conversion of $T_{4}$ to $T_{3}$ is not significant under these conditions. Both control and Graves' disease $\mathrm{Tg}$ were digested equally well by Pronase. The origin iodine was less than $5 \%$ of the total for three different samples from both control and propranololtreated Graves' Tg.

Heterogeneity of human Tg. Human goiter $\mathrm{Tg}$ is known to be heterogeneous in its iodine content (8). To determine whether or not the lower $T_{4} / T_{3}$ ratio was characteristic of all of the $\mathrm{Tg}$ present in the thyroids of patients with Grave's disease, it was fractionated into proteins of varying iodine content, using $\mathrm{RbCl}$ density gradient centrifugation. Typical patterns

2 Zimmerman, C. J., M. Izumi, and P. R. Larsen. Manuscript submitted for publication. of $\mathrm{Tg}$ obtained using this technique are presented in Fig. 2. As with the gel-filtration elution profile, there appeared to be no significant difference between the pattern in Graves' disease and that of controls. After determination of protein concentration, the fractions were pooled into four groups, A-D, as indicated by the lines in Fig. 2. Iodine determinations and Pronase digestion were performed on the pooled subfractions. The iodine content of the four fractions followed a consistent pattern. It was lowest in the A fraction, and reached a peak in fraction $C$, while that of the $\mathrm{B}$ fraction was intermediate. The iodine content of the $\mathrm{D}$ fraction was the same or slightly lower than that of the $\mathrm{C}$ fraction. The data presented in Table IV shows the efficiency of this separation technique analyzed by comparing the $\mathrm{Tg}$ iodine content of the $A$ and $C$ fractions. In addition, the $T_{4} / T_{3}$ ratios calculated for the $\mathrm{Tg}$ in the same fractions are also presented. In the control specimens, the mean number of iodine atoms per molecule Tg was 14 in the A fractions whereas in the $\mathrm{C}$ fractions it was 19 . These values are significantly different and demonstrate the successful partition of the $\mathrm{Tg}$ molecules according to iodine content. A larger gradient is seen in the Graves' disease $\mathrm{Tg}$ where the iodine/ $\mathrm{Tg}$ ratio was 13 in the $A$ fractions and 24 in the $C$ fractions. Despite the significant differences in iodine content of the $\mathrm{Tg}$ from the $\mathrm{A}$ and $\mathrm{C}$ fractions, the molar ratio of $T_{4} / T_{3}$ was not different, either in the normals, or in the patients with Graves' disease. Thus, it appeared that the $T_{4} / T_{3}$ molar ratio was in-

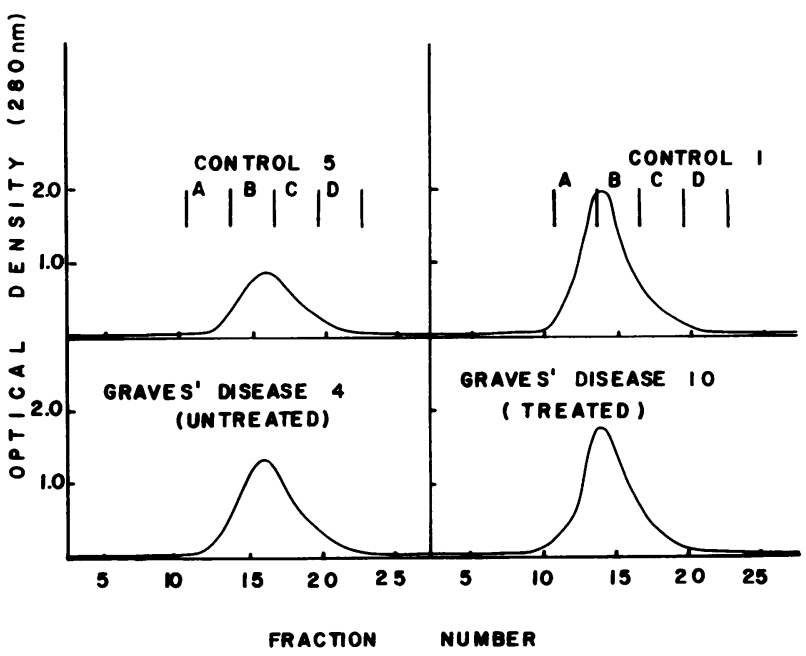

FIGURE 2 Representative profiles of $\mathrm{Tg}$ after isopycnic equilibrium density gradient ultracentrifugation in $34.5 \%$ $\mathrm{RbCl}$. Each fraction is $0.2 \mathrm{ml}$. The upper portion of the tube is to the left. The divisions, A-D show which fractions were pooled to evaluate the relationship between $T_{3}, T_{4}$, and iodine content of the $\mathrm{Tg}$. Results of four different preparations are depicted. The terms "treated" and "untreated" refer to thiourea drugs and iodide. 
dependent of the iodination of the $\mathrm{Tg}$ within a single gland as it was partitioned in these studies.

$\mathrm{T}_{3} \mathrm{Tg}$ and $\mathrm{T}_{4} / \mathrm{Tg}$ in $\mathrm{RbCl}$ subfractions. The separation of $\mathrm{Tg}$ into four subfractions allowed an analysis of the relationship between the $T_{3}$ and $T_{4}$ and iodination of the $\mathrm{Tg}$ over a broad range of iodine content. There were 23 subfractions of normal $\mathrm{Tg}$ and 40 subfractions of $\mathrm{Tg}$ from treated and untreated patients with Graves' disease. Figs. 3-5 show the relationship between the $T_{3} / T g, T_{4} / T g$, and $T_{4} / T_{3}$ molar ratios and iodine content for all subfractions. In Fig. 3, there appears to be a higher $\mathrm{T}_{3} / \mathrm{Tg}$ ratio in Graves' disease $\mathrm{Tg}$ at any level of iodine content. The $\mathrm{T}_{3} / \mathrm{Tg}$ ratio was significantly higher in the propranololtreated Graves' patients as opposed to control subjects

TABLE IV

Comparison of Iodine Content and $\mathrm{T}_{4} / \mathrm{T}_{3}$ Ratio in $\mathrm{RbCl}$ Density Gradient Fractions of Human Tg

\begin{tabular}{|c|c|c|c|c|c|c|c|}
\hline \multicolumn{4}{|c|}{ Control } & \multicolumn{4}{|c|}{ Graves' disease } \\
\hline Sample & $\begin{array}{c}\mathrm{RbCl} \\
\text { fraction }\end{array}$ & $\mathrm{I} / \mathrm{Tg}$ & $T_{\sqrt{ }} T_{3}$ & Sample & $\begin{array}{c}\mathrm{RbCl} \\
\text { fraction }\end{array}$ & $\mathbf{I} / \mathrm{Tg}$ & $T_{\sqrt{ }} T_{3}$ \\
\hline & & $\begin{array}{c}\text { atoms } / \\
\text { molecule }\end{array}$ & $\begin{array}{l}\text { molar } \\
\text { ratio }\end{array}$ & & & $\begin{array}{c}\text { atoms } 1 \\
\text { molecule }\end{array}$ & $\begin{array}{l}\text { molar } \\
\text { ratio }\end{array}$ \\
\hline 1 & $\begin{array}{l}\text { A } \\
\text { C }\end{array}$ & $\begin{array}{l}6.4 \\
5.2\end{array}$ & $\begin{array}{l}7.2 \\
5.6\end{array}$ & 1 & $\begin{array}{l}\text { A } \\
\text { C }\end{array}$ & $\begin{array}{l}10 \\
16\end{array}$ & $\begin{array}{l}14 \\
13\end{array}$ \\
\hline 2 & $\begin{array}{l}\text { A } \\
\text { C }\end{array}$ & $\begin{array}{c}5.9 \\
11\end{array}$ & $\begin{array}{l}15 \\
11\end{array}$ & 2 & $\begin{array}{l}\text { A } \\
\text { C }\end{array}$ & $\begin{array}{l}20 \\
30\end{array}$ & $\begin{array}{l}14 \\
15\end{array}$ \\
\hline 3 & $\begin{array}{l}\text { A } \\
\text { C }\end{array}$ & $\begin{array}{l}16 \\
18\end{array}$ & $\begin{array}{l}19 \\
17\end{array}$ & 3 & $\begin{array}{l}\text { A } \\
\text { C }\end{array}$ & $\begin{array}{l}13 \\
25\end{array}$ & $\begin{array}{l}9.3 \\
8.3\end{array}$ \\
\hline 4 & $\begin{array}{l}\text { A } \\
\text { C }\end{array}$ & $\begin{array}{l}15 \\
22\end{array}$ & $\begin{array}{r}7 \\
10\end{array}$ & 4 & $\begin{array}{l}\text { A } \\
\text { C }\end{array}$ & $\begin{array}{l}16 \\
31\end{array}$ & $\begin{array}{l}5.9 \\
12\end{array}$ \\
\hline 5 & $\begin{array}{l}\text { A } \\
\text { C }\end{array}$ & $\begin{array}{l}18 \\
29\end{array}$ & $\begin{array}{l}17 \\
14\end{array}$ & 5 & $\begin{array}{l}\text { A } \\
\text { C }\end{array}$ & $\begin{array}{l}19 \\
32\end{array}$ & $\begin{array}{l}12 \\
12\end{array}$ \\
\hline 6 & $\begin{array}{l}\text { A } \\
\text { C }\end{array}$ & $\begin{array}{l}22 \\
31\end{array}$ & $\begin{array}{l}15 \\
16\end{array}$ & 6 & $\begin{array}{l}\text { A } \\
\text { C }\end{array}$ & $\begin{array}{l}20 \\
39\end{array}$ & $\begin{array}{l}7.3 \\
8.4\end{array}$ \\
\hline $\begin{array}{c}\text { Mean } \\
\text { SE }\end{array}$ & A & $\begin{array}{c}14 \\
2.6\end{array}$ & $\begin{array}{l}13 \\
2.1\end{array}$ & 7 & $\begin{array}{l}\text { A } \\
\text { C }\end{array}$ & $\begin{array}{l}22 \\
37\end{array}$ & $\begin{array}{l}7.2 \\
8.2\end{array}$ \\
\hline Mean & C & $\begin{array}{c}19^{*} \\
4.1\end{array}$ & $\begin{array}{l}12 \\
1.7\end{array}$ & 8 & $\begin{array}{l}\text { A } \\
\text { C }\end{array}$ & $\begin{array}{l}3.6 \\
6.8\end{array}$ & $\begin{array}{l}4.4 \\
2.8\end{array}$ \\
\hline & & & & 9 & $\begin{array}{l}\text { A } \\
\text { C }\end{array}$ & $\begin{array}{l}4.4 \\
8.2\end{array}$ & $\begin{array}{l}2.4 \\
3.6\end{array}$ \\
\hline & & & & 10 & $\begin{array}{l}\text { A } \\
\text { C }\end{array}$ & $\begin{array}{l}6.0 \\
11\end{array}$ & $\begin{array}{l}8.4 \\
4.9\end{array}$ \\
\hline & & & & $\begin{array}{c}\text { Mean } \\
\text { SE }\end{array}$ & A & $\begin{array}{c}13 \\
2.2\end{array}$ & $\begin{array}{l}8.5 \\
3.9\end{array}$ \\
\hline & & & & $\begin{array}{c}\text { Mean } \\
\text { SE }\end{array}$ & C & $\begin{array}{r}24 \ddagger \\
3.8\end{array}$ & $\begin{array}{l}8.8 \\
1.3\end{array}$ \\
\hline
\end{tabular}

* Different from A, $P<0.05$.

$\$$ Different from A, $P<0.005$.

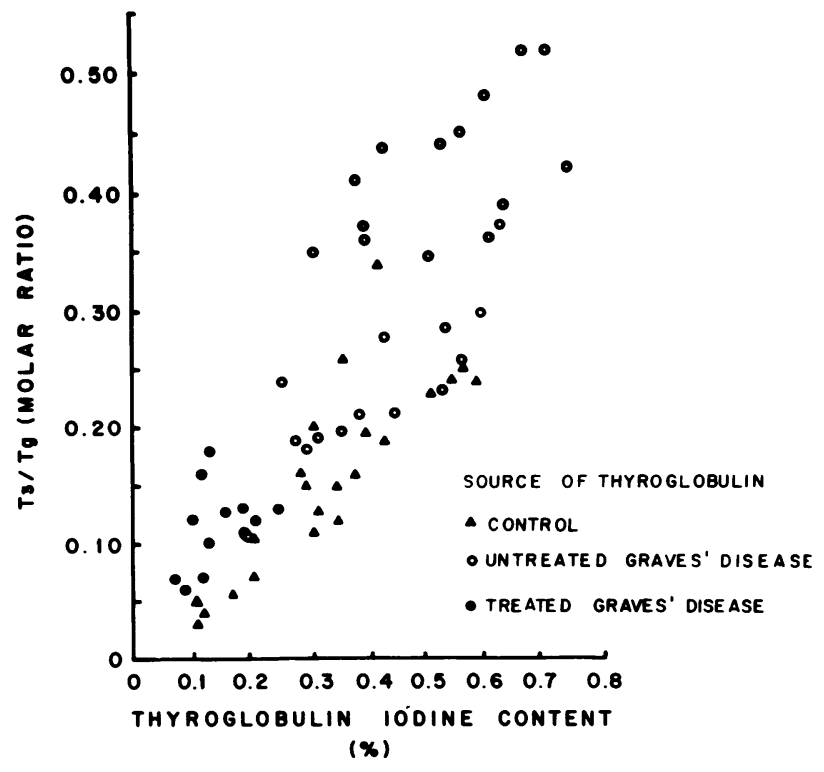

FIGURE 3 Relationship between the $\mathrm{T}_{3} / \mathrm{Tg}$ molar ratio and iodine content of the subfractions of humn $\mathrm{Tg}$ obtained by $\mathrm{RbCl}$ density gradient centrifugation. $\mathrm{T}_{3}$ content was determined by immunoassay after Pronase digestion of the purified $\mathrm{Tg}$.

with $P=0.003$ by the Fisher's Exact Treatment (12). On the other hand, there was a great overlap between the controls and Graves disease groups in the $T_{4} / \mathrm{Tg}$ molar ratios (Fig. 4). As was the case with the analyses of the whole $\mathrm{Tg}$ preparations (Table III), the $\mathrm{T}_{4} / \mathrm{T}_{3}$ molar ratios in the $\mathrm{RbCl}$ subfractions were significantly higher in normal $\mathrm{Tg}$ than in $\mathrm{Tg}$ from patients with propranolol-treated Graves' disease $(P=0.013$, Fisher's Extract Treatment). These results are presented in Fig. 5.

\section{DISCUSSION}

Much of the previous data in the literature relative to the iodothyronine content of human thyroid tissue or $\mathrm{Tg}$ is derived from studies obtained using tissue from patients treated preoperatively with labeled iodine. In this method, the thyroid tissue was then digested and labeled compounds were separated by chromatography with iodine content being measured in each fraction. There are two technical problems with this analytical approach for $T_{3}$ and $T_{4}$ determinations. The first is that chromatography generally results in deiodination of $\mathrm{T}_{4}$ with some of this appearing as $T_{3}$ artifactually increasing the $T_{3} / T_{4}$ ratio $(13,14)$. Secondly, tracer iodine given on a single occasion within a few days of surgery is not homogeneously distributed within the thyroid gland. Heterogeneity, both with respect to the iodination of $\mathrm{Tg}$ within a follicle as well as between follicles in various portions of the thyroid gland has been clearly demonstrated $(15,16)$. The radioimmunoassay tech-

$T_{3}, T_{4}$ and Iodine in Human Thyroglobulin 1109 


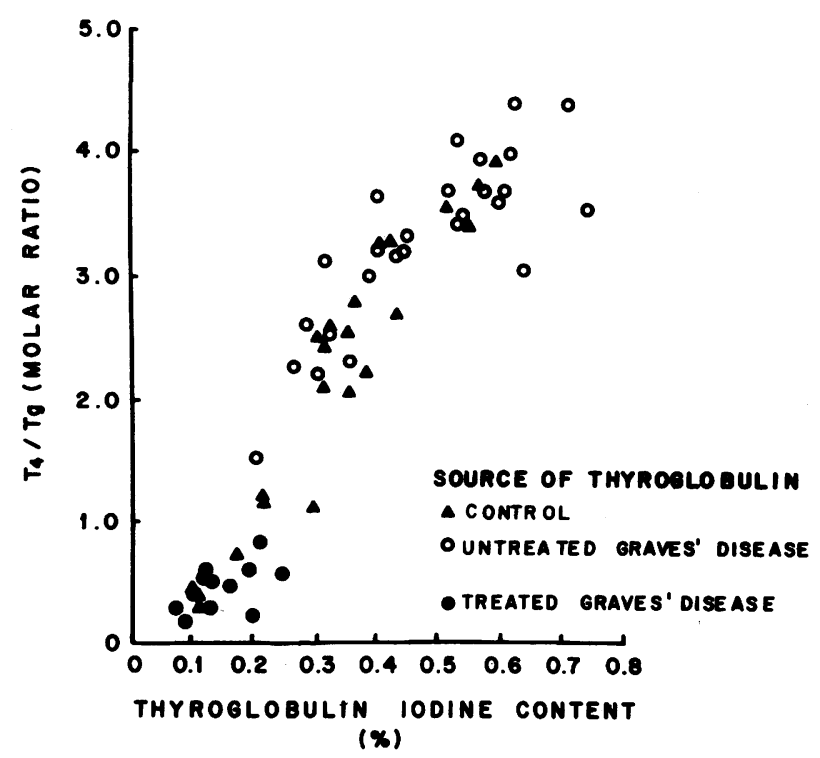

FIgURE 4 Relationship between the $\mathrm{T}_{4} / \mathrm{Tg}$ molar ratio and the iodine content of the subfractions of human $\mathrm{Tg}$ obtained by $\mathrm{RbCl}$ density gradient centrifugation. $\mathrm{T}_{4}$ content was determined by radioimmunoassay after Pronase digestion of the purified $\mathrm{Tg}$.

niques used in this study circumvent both of these problems. The methodological studies presented above indicate that there is no significant conversion of $T_{4}$ to $T_{3}$ during the Pronase digestion process and that digestion of the two types of $\mathrm{Tg}$ is equally complete with respect to organic iodine.

The range of iodine content observed in normal $\mathrm{Tg}$ was from 0.13 to $0.65 \%$ similar to that observed by many other investigators (17). With the exception of the first $\mathrm{Tg}$ preparation, the $\mathrm{T}_{4}$ iodine constituted approximately $46 \%$ of the total $\mathrm{Tg}$ iodine. This is not statistically different from that observed in a group of 12 normal specimens of purified $\mathrm{Tg}$ examined by Rolland et al. (18). Because of the difficulty in quantitating the small quantities of $T_{3}$ accurately without immunoassay due to the artifacts mentioned previously, there are no reliable estimates of its concentration in normal human $\mathrm{Tg}$. The present results suggest that only about one in five molecules of well-iodinated human $\mathrm{Tg}$ contains a $\mathrm{T}_{3}$ residue as opposed to an average of 3.4 residues of $T_{4} /$ molecule $T g$, a $T_{4} / T_{3}$ molar ratio of $15 / 1$. This results can be compared to several recent studies, of human thyroid homogenates, which have used either careful chromatographic separation or immunoassay techniques. Nagataki et al. reported a $T_{4} / T_{3}$ molar ratio of 9.2 (19) and Chopra et al. a ratio of 19 (20). Our previous studies gave results of 13 and 11 for $T_{4} / T_{3}$ ratio in homogenates of normal human thyroids $(4,21)$.

The iodine content of the $\mathrm{Tg}$ from seven propranolol- treated patients with Graves' disease was normal. Because the usual approach to presurgical therapy of patients with this disease includes antithyroid drugs and iodine, there have been no recent systematic studies of tissue from subjects who have not received agents known to alter thyroid function. In one series, a mean value of $0.17 \%$ was found in six apparently untreated patients living in France (18). Whether this lower value results from differences in methodology or in the iodine content of the patients' diet is unknown. The percent $T_{4}$ iodine in that report varied between 7 and $49 \%$ depending on the iodine content of the $\mathrm{Tg}$. This was similar to normal $\mathrm{Tg}$ in that study, but the data was insufficient to allow valid comparisons with the $T_{3}$ content of normal $\mathrm{Tg}$. The present studies indicate that the percent $\mathrm{Tg}$ iodine as $\mathrm{T}_{4}$ in these subjects is $49 \%$, not different from that in normal $\mathrm{Tg}$. The percent $\mathrm{T}_{3}$ iodine was significantly increased resulting in a reduction in the molar ratio of $T_{4} / T_{3}$ to $9 / 1$. This percent $T_{3}$ iodine is about 1.7 times that which we found in normal $\mathrm{Tg}$.

The results presented in Fig. 3 indicate that at all levels of iodination which are present in these human $\mathrm{Tg}$ samples, the $\mathrm{T}_{3} / \mathrm{Tg}$ ratio is higher in the Graves' disease $\mathrm{Tg}$ than in the control material. Because there is little difference in the $T_{4} / T g$ molar ratio (Fig. 4), the calculated $T_{4} / T_{3}$ ratio is significantly lower in Graves' disease. The uniformity of these observations in the $\mathrm{RbCl}$ subfractions of differing iodine content (Fig. 5) suggests that the higher $\mathrm{T}_{3} / \mathrm{Tg}$ molar ratio is characteristic of all components of the $\mathrm{Tg}$ pool. The possibility that two pools of $\mathrm{Tg}$ might exist in Graves' thyroid, one with a reduced iodine content and low $T_{4} / T_{3}$ ratio and a second with normal

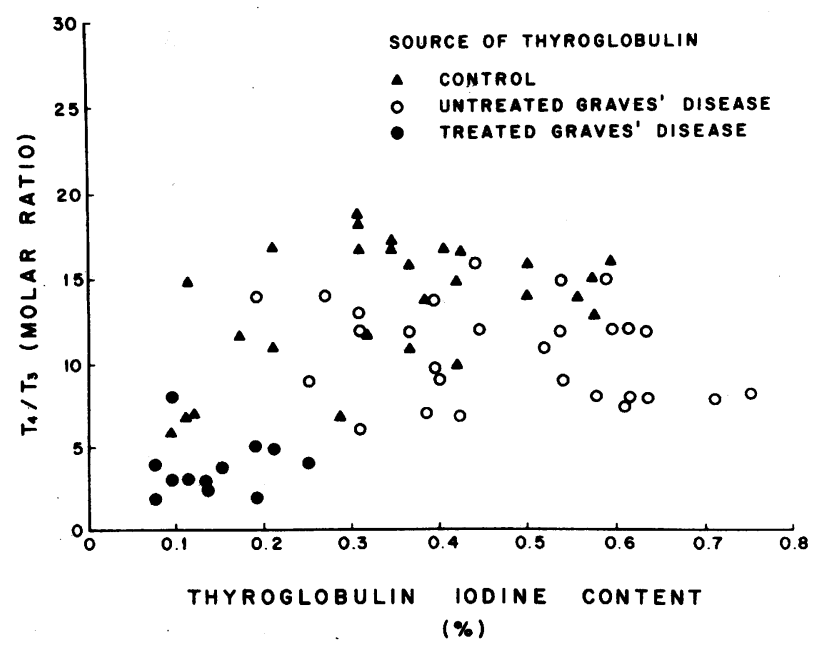

FIGURE 5 Relationship between the $T_{4} / T_{3}$ ratio and iodine content of the subfractions of human $\mathrm{Tg}$ obtained by $\mathrm{RbCl}$ density gradient centrifugation. 
$\mathrm{I} / \mathrm{Tg}$ and $\mathrm{T}_{3} / \mathrm{Tg}$ ratios, seems therefore eliminated. The exclusion of this possibility was the major reason for performing the $\mathrm{RbCl}$ fractionation studies. We were somewhat surprised not to find a lower $T_{4} / T_{3}$ ratio in the $\mathrm{A}$, as opposed to the $\mathrm{C}$, fractions from both control and Graves' disease Tg as one might expect more recently synthesized $\mathrm{Tg}$ to have a lower $\mathrm{I} / \mathrm{Tg}$ ratio and therefore a lower $T_{4} / T_{3}$ ratio. We have demonstrated the latter phenomenon in normal and iodine-deficient rats (22). A possible explanation is that this pool of recently synthesized $\mathrm{Tg}$ comprises such a small portion of the total pool that its characteristics are lost even in the $\mathrm{A}$ subfraction.

The reason for the higher $T_{3}$ content of Graves' $\mathrm{Tg}$ as opposed to normal is not known. Since the Tg did not appear to be deficient in iodine, this explanation could not be used for these particular findings. Furthermore, in iodine-deficient rats, both the $\mathrm{T}_{3}$ and $\mathrm{T}_{4}$ content of $\mathrm{Tg}$ are reduced, the reduction in the latter being greater (10). This change gives rise to the high molar ratio of $\mathrm{T}_{3} / \mathrm{T}_{4}$ characteristic of this condition. Such a situation is seen in the three patients with treated Graves' disease, where the reduction in $\mathrm{T}_{4}$ from what is observed in either normal or propranolol-treated Graves' $\mathrm{Tg}$ exceeds the reduction in $\mathrm{T}_{3}$ on a percentage basis. The molar ratio, $T_{3} / T_{4}$, is increased even further in these glands than in propranolol-treated patients.

Thyroid peroxidase has been demonstrated to have a stimulatory catalytic action on the rate of coupling of diiodotyrosine to $T_{4}$ in vitro (23). The activity of this enzyme has been recently reported to be three to four times normal in thyroid tissues from patients with Graves' disease (24). It is conceivable that in Graves' disease, coupling of critical iodotyrosyl residues might occur before their attaining the level of iodination which would be anticipated from the available iodine supply. Thus instead of 2-diiodotyrosyl residues combining to form $T_{4}$, earlier coupling might involve a mono- and a diiodotyrosine giving rise to $T_{3}$. An iodine-independent stimulatory effect of thyroid-stimulating hormone on coupling has been demonstrated in hypophysectomized rats by Greer et al. (25) and in thyroid-stimulating hormone-treated guinea pigs by Dunn and Ray (26). Whether or not thyroidal peroxidase is involved in this stimulation is unclear, but the Graves' disease thyroid is clearly stimulated by some factor. It would not appear that propranolol, which appears to have no effect either on thyroidal iodine metabolism or the serum concentrations of thyroid hormones in patients with hyperthyroidism could be implicated in this effect $(27,28)$.

Our previous measurements of serum $T_{3}$ and $T_{4}$ in patients with hyperthyroidism due to Graves' disease have indicated that the mean total serum $\mathrm{T}_{3}$ concentra- tion is 4.3 times normal and that of $T_{4}, 2.7$ times normal (3). The molar ratio of $T_{4} / T_{3}$ in the serum of normal subjects was $60 \pm 3($ mean $\pm \mathrm{SE})$ and was $40 \pm 2$ in the hyperthyroid group. If this apparent relative hyperproduction of $T_{3}$ is due solely to an increase in the ratio of $T_{3} / T_{4}$ in the secreted hormones, fractional peripheral $T_{4} / T_{3}$ conversion remaining unchanged, then one would predict an approximate 1.5-fold higher $T_{3} / T_{4}$ ratio in the secreted hormones. This is slightly less than the 1.7 -fold difference that we observed. If the ratio of secreted hormones is similar to that present in the $\mathrm{Tg}$, then this relatively small increase in the $T_{3} / \mathrm{Tg}$ ratio could explain the hyperproduction of $\mathrm{T}_{3}$ in patients with Grave's disease. It would also suggest that the condition known as " $\mathrm{T}_{3}$ thyrotoxicosis" is a more exaggerated form of this abnormality, perhaps influenced by the level of intrathyroidal iodine. We would conclude, therefore, that while the total quantity of the iodothyronines in the human thyroid is directly related to the iodine content of the $\mathrm{Tg}$, there is another factor (or factors), one of which is present in patients with Graves' disease, which can alter the ratio of $T_{3}$ to $T_{4}$ present in the $\mathrm{Tg}$ and presumably in the secreted hormones.

\section{ACKNOWLEDGMENTS}

The authors would like to acknowledge the careful technical assistance of Mr. Maurice Castonguay and thank Ms. Anne Duli for preparation of the manuscript. We are grateful for the cooperation of Dr. John J. Canary, Georgetown University School of Medicine and the Departments of Surgery and Pathology, Peter Bent Brigham Hospital.

This work was supported by National Institutes of Health grant 5 R01 AM18616-02.

\section{REFERENCES}

1. Larsen, P. R. 1972. Triiodothyronine: a review of recent studies of the physiology and pathophysiology in man. Metab. Clin. Exp. 21: 1073-1092.

2. Sterling, K., S. Refetoff, and H. A. Selenkow. 1970. $\mathrm{T}_{3}$ thyrotoxicosis. Thyrotoxicosis due to elevated serum triiodothyronine levels. J. Am. Med. Assoc. 213: 571-575.

3. Abuid, J., and P. R. Larsen. 1974. Triiodothyronine and thyroxine in hyperthyroidism: Comparison of the acute changes during therapy with antithyroid agents. J. Clin. Invest. 54: 201-208.

4. Larsen, P. R. 1975. Thyroidal triiodothyronine and thyroxine in Graves' disease: Correlation with presurgical treatment, thyroid status, and iodine content. J. Clin. Endocrinol. Metab. 41: 1098-1104.

5. Studer, H., and M. A. Greer. 1965. A study of the mechanisms involved in the production of iodine-deficiency goiter. Acta Endocrinol 49: 610-628.

6. Robbins, J. 1972. Thyroid proteins. In Methods in Investigative and Diagnostic Endocrinology. S. Berson, editor. North-Holland Publishing Co., Amsterdam. 1: 82-99.

7. Bilstad, J. M., H. Edelhoch, R. Lippoldt, J. E. Rall, and G. Salvatore. 1972. Isolation and characterization of 
discrete fragments of $27 \mathrm{~S}$ thyroid iodoprotein. Arch. Biochem. Biophys. 151: 341-350.

8. Schneider, A. B., and H. Edelhoch. 1971. Equilibrium density centrifugation of thyroglobulin in $\mathrm{RbCl}$. Effect of iodine. J. Biol. Chem. 246: 6592-6598.

9. Inoue, K., and A. Taurog. 1967. Digestion of ${ }^{131} \mathrm{I}-$ labeled thyroid tissue with maximum recovery of ${ }^{131} \mathrm{I}$ iodothyronines. Endocrinology. 81: 319-332.

10. Abrams, G. M., and P. R. Larsen. 1973. Triiodothyronine and thyroxine in the serum and thyroid glands of iodine-deficient rats. J. Clin. Invest. 52: 2522-2531.

11. Snedecor, G. W., and W. G. Cochran. 1967. Statistical Methods. The Iowa State University Press, Ames, Iowa. 6th edition. 100-101.

12. Fisher, R. A. 1970. Statistical Methods for Research Workers. Hafner Press, New York. 14th edition. 96-98.

13. Larsen, P. R. 1971. Technical aspects of the estimation of triiodothyronine in human serum: evidence of conversion of thyroxine to triiodothyronine during assay. Metab. Clin. Exp. 20: 609-624.

14. Dussault, J. H., R. Lam, and D. A. Fisher. 1971. The measurement of serum triiodothyronine by double column chromatography. J. Lab. Clin. Med. 77: 10391050 .

15. Loewenstein, J. E., and S. H. Wollman. 1967. Kinetics of equilibrium labeling of the rat thyroid gland with ${ }^{125}$ I. Endocrinology. 81: 1063-1073.

16. Loewenstein, J. E., and S. H. Wollman. 1967. Distribution of organic ${ }^{125} \mathrm{I}$ and ${ }^{127} \mathrm{I}$ in the rat thyroid gland during equilibrium labeling as determined by autoradiography. Endocrinology. 81: 1074-1085.

17. Salvatore, G., and H. Edelhoch. 1970. Chemistry and biosynthesis of thyroid iodoproteins. In Hormonal Proteins and Peptides. Academic Press, Inc., New York, 201-241.

18. Rolland, M., M. F. Montfort, L. Valenta, and S. Lissitzky. 1972. Iodoamino acid composition of the thyroglobulin of normal and diseased thyroid glands. Comparison with in vitro iodinated thyroglobulin. Clin. Chim. Acta. 39: 95- 108 .

19. Nagataki, S., H. Uchimura, Y. Masuyama, K. Nakao, and K. Ito. 1972. Triiodothyronine and thyroxine in thyroid glands of euthyroid Japanese subjects. J. Clin. Endocrinol. Metab. 35: 18-23.

20. Chopra, I. J., D. A. Fisher, D. H. Solomon, and G. N. Beall. 1973. Thyroxine and triiodothyronine in the human thyroid. J. Clin. Endocrinol. Metab. 36: 311-316.

21. Larsen, P. R., K. Yamashita, A. Dekker, and J. B. Field. 1973. Biochemical observations in functioning human thyroid adenomas. J. Clin. Endocrinol. Metab. 36: 10091018.

22. Riesco, G., A. Taurog, P. R. Larsen, and L. Krulich. 1977. Acute and chronic responses to iodine deficiency in rats. Endocrinology. 100: 303-313.

23. Lamas, L., M. L. Doris, and A. Taurog. 1972. Evidence for a catalytic role for thyroid peroxidase in the conversion of diiodotyrosine to thyroxine. Endocrinology. 90: 1417- 1426.

24. Valenta, L. J. 1976. Thyroid peroxidase, thyroglobulin, cAMP and DNA in human thyroid. J. Clin. Endocrinol. Metab. 43: 466-469.

25. Greer, M. A., C. F. Allen, J. Torresani, M. Roques, and S. Lissitzky. 1974. TSH stimulation of iodothyronine formation in prelabeled thyroglobulin of hypophysectomized rats. Endocrinology. 94: 1224-1231.

26. Dunn, J. T., and S. C. Ray. 1975. Changes in the structure of thyroglobulin following the administration of thyroid-stimulating hormone.J. Biol. Chem. 250: 5801-5807.

27. Azizi, F., A. G. Vagenakis, J. E. Bush, and L. E. Braverman. 1974. Effect of propranolol on various aspects of thyroid function in the rat. Metab. Clin. Exp. 23: 525-529.

28. Wartofsky, L., R. C. Dimond, G. L. Noel, A. G. Frantz, and J. M. Earll. 1975. Failure of propranolol to alter thyroid iodine release, thyroxine turnover, or the TSH and PRL responses to thyrotropin-releasing hormone in patients with thyrotoxicosis. J. Clin. Endocrinol. Metab. 41: 485-490. 